Biological and Clinical Sciences Research Journal

ISSN: 2708-2261

www.bcsrj.com

DOI: https://doi.org/10.54112/bcsri.v2021i1.65

Biol. Clin. Sci. Res. J., Volume, 2020: 65

Original Research Article

\title{
EFFECTS OF SEED PRIMING WITH SALICYLIC ACID ON ZEA MAYS SEEDLINGS GROWN UNDER SALT STRESS CONDITIONS
}

\section{*IQBAL S, ALI Q, MALIK A}

\author{
Institute of Molecular Biology and Biotechnology, The University of Lahore, Lahore, Pakistan \\ *Corresponding author email: saratarar580@gmail.com
}

(Received, $20^{\text {th }}$ September 2020, Revised $18^{\text {th }}$ May 2021, Published $21^{\text {th }}$ May 2021)

\begin{abstract}
Maize crop is cultivated as the 3rd most important cereal crop after wheat and rice in Pakistan. As an exhaustive crop maize required all essential nutrients at all crop growth stages. Among essential nutrients nitrogen involved with the greenish colors of the vegetative parts, leaves production, branching and end up with drier biomass. Hydro-priming and osmo-priming are the commonly used priming techniques. In both techniques the seeds were soaked in treatments for overnight followed by air drying before sowing. To overcome several a-biotic stresses of field crops seed priming techniques have been used globally. The current study was planned to evaluate effect of different salt treatments on the growth traits of maize. Two maize verities Raka-Poshi and Pak-Afgoi were evaluated for the effect of salts stress on maize. Three salts ZnSO4, MgSO4 and NaCl were used @0.5 M and 0.25M solutions. Treatments used in the experiment were ZnSO4 (0.5M), ZnSO4 (0.25M), MgSO4 (0.5M), $\mathrm{MgSO} 4(0.25 \mathrm{M}), \mathrm{NaCl}$ (0.5M), $\mathrm{NaCl}(0.25 \mathrm{M}), \mathrm{ZnSO} 4(0.5 \mathrm{M})+\mathrm{MgSO} 4(0.5 \mathrm{M}), \mathrm{ZnSO} 4(0.25 \mathrm{M})+\mathrm{MgSO} 4(0.5 \mathrm{M}), \mathrm{ZnSO4}(0.5 \mathrm{M})+$ $\mathrm{MgSO} 4$ (0.25M), ZnSO4 (0.25M) + MgSO4 (0.25M), ZnSO4 (0.5M) + NaCl (0.5M), ZnSO4 0.25M + NaCl (0.5M), $\mathrm{ZnSO} 4(0.5 \mathrm{M})+\mathrm{NaCl}(0.25 \mathrm{M}), \quad \mathrm{ZnSO} 4(0.25 \mathrm{M})+\mathrm{NaCl}(0.25 \mathrm{M}), \mathrm{ZnSO} 4(0.5 \mathrm{M})+\mathrm{MgSO} 4(0.5 \mathrm{M})+\mathrm{NaCl}$ $(0.5 \mathrm{M})$, ZnSO4 (0.25M) + MgSO4 (0.25M) + NaCl (0.25M). Maximum growth was observed in the plants that were primed with ZnSO4 used alone@0.5M and 0.25M or in combination with MgSO4. However, NaCl retard the growth of plant used alone or in combination with other salts. Seed priming by $30 \mathrm{mg} / \mathrm{l}$ salicylic acid solution not only found vital to enhance the uniform seed germination and rate of seed germination but also are environment friendly, simple, low cost low risk techniques and easily adoptable.
\end{abstract}

Keywords: Zea mays, salt stress, seed priming, seedling biomass, exhaustive crop

as compared to the developed countries. The

\section{Introduction}

Maize crop is cultivated as the $3^{\text {rd }}$ most important cereal crop after wheat and rice in Pakistan. The total area under maize cultivation in Pakistan is around 1083 thousand hectares with the annual production of 4271 thousand tones and 15\% increase in yield has been observed in comparison with the previous years (GOP, 2012). Among all provinces of the country about 98 percent maize crop is cultivated in Punjab and KPK (Anonymous, 2010). In developing countries like Pakistan maize is cultivated both for food and fodder. Maize grains not only confined to food and feed but also used in many commercial products. With the increase in human population and growing live stock industry the demand of maize also increased. With high yield potential and being short duration crop maize can be significant to boost the economy of developing countries like Pakistan. The average grains yield of maize crop in Pakistan is low biological potential of available maize cultivars has not been explored due to biotic and a-biotic factors. Timely and balanced dose of micro and macro nutrients are very important to maximize the maize crop yield (Aaliya et al., 2016; Ali et al., 2013; Asghar et al., 2010). As an exhaustive crop maize required all essential nutrients at all crop growth stages. Among essential nutrients nitrogen involved with the greenish colors of the vegetative parts, leaves production, branching and end up with more dry biomass (Ali et al., 2014; Ali et al., 2016; Rashidi et al., 2015). In maize crop zinc ( $\mathrm{Zn})$ deficiency is very common (Cakmak et al., 1999 and Graham et $a l ., 1992$ ) and maize crop found very sensitive to $\mathrm{Zn}$ deficiency (Mengel and Kirkby 1982). For plant growth and metabolism processes micronutrient $\mathrm{Zn}$ is very essential. $\mathrm{Zn}$ plays vital role in root development, enzyme formation, carbohydrate regulation, and chlorophyll cytochrome pigment and 
auxins formation. Due to the high solvency the use of zinc sulphate is common as compared to any other $\mathrm{Zn}$ fertilizer (Ali et al., 2017; Rehm and Schmitt 1997; Zubair et al., 2016). Whereas in Pakistan only 5 percent farming community use proper zinc fertilizers (FAO 2004).

Pre-sowing treatment in water or any other solutions that allow the seeds to imbibe with water or other applied solution to continue the initial stage of germination is described as seed priming. Seed priming not only plays vital role in early plant stages but also significantly improve the uniform rate of seed germination (Basra et al., 2005, Farooq et al., 2006a, Farooq et al., 2006b, Farooq et al., 2006c). Now a day's a number of seed priming techniques are used by the farmers and reported by researcher that performs better under unfavorable conditions. Hydropriming and osmo-priming are the commonly used priming techniques. In both techniques the seeds are soaked in treatments for overnight followed by air drying before sowing (Ashraf and Foolad 2005). The rate of seed germination in tropical crops such as chickpea, rice, wheat, maize and sorghum enhanced with hydro-priming (Harris, D., 1996). To overcome several a-biotic stresses of field crops seed priming techniques have been used globally (Farooq et al., 2008a, and Farooq et al., 2009). Seed priming with $\mathrm{ZnSO}_{4}$ solution significantly improved the grain yield in maize (27\%), chickpea (18\%) and wheat (17\%) under diverse climatic conditions whereas, the outcomes shows similar trends maize $(26 \%)$ and wheat (16\%) reported by Harris et al.(2005) and (Harris et al., 2007). In fine and coarse rice the rate of nursery seedlings considerably improved by priming with $\mathrm{CaCl}_{2}$ (Farooq et al., 2007b) moreover in rice low temperature tolerance also improved (Zheng et al., 2002). Seed priming in late sown wheat with $\mathrm{CaCl} 2$ shows resistant against low temperature (Farooq et al., 2008a) similarly cotton seeds priming with glycinebetaine enable cotton to perform in drought (Naidu et al., 1998). Seed priming techniques not only found vital to enhance the uniform seed germination and rate of seed germination but also are environment friendly, simple, low cost low risk techniques and easily adoptable (Harris, D., 2006).

\section{Materials and methods}

The current study was performed at Laboratory of Institute of Molecular Biology and Biotechnology, University of Lahore. Seeds of two varieties (RakaPoshi and Pak-Afgoi) of Zea mays were obtained from Ayub Agricultural Research Institute, Faisalabad. For this study three salts were selected $\mathrm{ZnSO}_{4}, \mathrm{MgSO}_{4}$ and $\mathrm{NaCl} .30 \mathrm{mg} / \mathrm{l}$ salicylic acid solution was used for seed priming before sowing. The treatments of salt solutions used were as followed:

\begin{tabular}{|c|c|c|}
\hline i. & $\mathrm{T}_{0}$ & Control \\
\hline ii. & $\mathrm{T}_{1}$ & $\mathrm{ZnSO}_{4}(0.5 \mathrm{M})$ \\
\hline iii. & $\mathrm{T}_{2}$ & $\mathrm{ZnSO}_{4}(0.25 \mathrm{M})$ \\
\hline iv. & $\mathrm{T}_{3}$ & $\mathrm{MgSO}_{4}(0.5 \mathrm{M})$ \\
\hline v. & $\mathrm{T}_{4}$ & $\mathrm{MgSO}_{4}(0.25 \mathrm{M})$ \\
\hline vi. & $\mathrm{T}_{5}$ & $\mathrm{NaCl}(0.5 \mathrm{M})$ \\
\hline vii. & $\mathrm{T}_{6}$ & $\mathrm{NaCl}(0.25 \mathrm{M})$ \\
\hline viii. & $\mathrm{T}_{7}$ & $\mathrm{ZnSO}_{4}(0.5 \mathrm{M})+\mathrm{MgSO}_{4}(0.5 \mathrm{M})$ \\
\hline ix. & $\mathrm{T}_{8}$ & $\mathrm{ZnSO}_{4}(0.25 \mathrm{M})+\mathrm{MgSO}_{4}(0.5 \mathrm{M})$ \\
\hline $\mathbf{x}$. & $\mathrm{T}_{9}$ & $\mathrm{ZnSO} 4(0.5 \mathrm{M})+\mathrm{MgSO}_{4}(0.25 \mathrm{M})$ \\
\hline xi. & $\mathrm{T}_{10}$ & $\mathrm{ZnSO}_{4}(0.25 \mathrm{M})+\mathrm{MgSO}_{4}(0.25 \mathrm{M})$ \\
\hline xii. & $\mathrm{T}_{11}$ & $\mathrm{ZnSO}_{4}(0.5 \mathrm{M})+\mathrm{NaCl}(0.5 \mathrm{M})$ \\
\hline xiii. & $\mathrm{T}_{12}$ & $\mathrm{ZnSO}_{4} 0.25 \mathrm{M}+\mathrm{NaCl}(0.5 \mathrm{M})$ \\
\hline xiv. & $\mathrm{T}_{13}$ & $\mathrm{ZnSO} 4(0.5 \mathrm{M})+\mathrm{NaCl}(0.25 \mathrm{M})$ \\
\hline $\mathbf{x v}$. & $\mathrm{T}_{14}$ & $\mathrm{ZnSO} 4(0.25 \mathrm{M})+\mathrm{NaCl}(0.25 \mathrm{M})$ \\
\hline xvi. & $\mathrm{T}_{15}$ & $\mathrm{ZnSO}_{4}(0.5 \mathrm{M})+\mathrm{MgSO}_{4}(0.5 \mathrm{M})$ \\
\hline & \multicolumn{2}{|c|}{$\mathrm{NaCl}(0.5 \mathrm{M})$} \\
\hline & $\begin{array}{l}\mathrm{T}_{16} \\
+\mathrm{N}\end{array}$ & $\begin{array}{l}\mathrm{ZnSO}_{4}(0.25 \mathrm{M})+\mathrm{MgSO}_{4}(0.25 \mathrm{M}) \\
(0.25 \mathrm{M})\end{array}$ \\
\hline
\end{tabular}

Before priming, the seeds were sterilized with 10 percent solution of sodium hypochlorite. Ten seeds of each variety were soaked in $30 \mathrm{mg} / \mathrm{l}$ salicylic acid solution of each treatment for 24 hours in a petri dish. Ten seeds of control were dipped in $10 \mathrm{ml}$ o distilled water. After seed priming the seeds were rinsed with distilled water and air dried at room temperature before sowing to avoid any microbial growth on seeds after sowing. All the seeds were sowed within 24 hours of the pre sowing treatment of seeds with salt solutions. Peat moss was used in pots to grow plants. Two pots containing five seeds of each treatment was sowed. Thirty two pots of each variety was sown and total of 66 pots were filled for sowing of the experiment for both verities and the control. Two pots were of control where seeds having no treatment of salt but were dipped in distilled water. After sowing the pots were irrigated with distilled water. The parameters under study were Shoot Length $(\mathrm{cm})$, Root Length $(\mathrm{cm})$, Leaf Length $(\mathrm{cm})$, Leaf Width (cm), Fresh Shoot Weight (g), Fresh Root

[Citation: Iqbal, S., Ali, Q., Malik, A. (2021). Effects of seed priming with salicylic acid on Zea mays seedlings grown under salt stress conditions. Biol. Clin. Sci. Res. J., 2021: 65. doi: https://doi.org/10.54112/bcsrj.v2021i1.65] 
Weight (g), Dry Shoot Weight (g), Dry Root Weight (g). First data were recorded seven days after the emergence of seedlings and subsequent data were recorded after a week interval for two weeks. On each data collection three plants were uprooted from the pots. Shoots were carefully separated from the roots and roots were thoroughly washed with distilled water. Shoot length, root length, leaf length and leaf width were measured in centimeters with measuring tape. Freshly emerging leaves and roots were not taken under consideration while recording the data of root length, leaf length and leaf width. Fresh shoot weight and fresh root weight were also measured in grams by using weigh balance. For dry shoot weight and dry root weight the sample of shots and roots were than oven dried at $100^{\circ} \mathrm{C}$ overnight in hot air oven and then the dry shoot and root weight was recorded. The data were analyzed by analysis of variance using the Statistix 8.1 and means were compare using least significant difference.

\section{Results and discussion}

The data regarding shoot length of both the verities revealed that the plants of Raka-Poshi maize seeds priming with $30 \mathrm{mg} / \mathrm{l}$ salicylic acid solution have the longest shoot length throughout the growth period however in Pak-Afgoi maize variety seeds priming with $30 \mathrm{mg} / \mathrm{l}$ salicylic acid solution under treatments of $\mathrm{NaCl}, \mathrm{ZnSO}_{4}$ salt have the longest shoot length during first week and in $2^{\text {nd }}$ and $3^{\text {rd }}$ weeks of growth the plants seeds priming with $30 \mathrm{mg} / \mathrm{l}$ salicylic acid solution have the longest shoot length respectively. In Raka-Poshi maize minimum growth regarding shoot length was recorded in plants treated with salts $\mathrm{ZnSO}_{4} 0.5 \mathrm{M}, \mathrm{MgSO}_{4} 0.5 \mathrm{M}$ and $\mathrm{NaCl} 0.5 \mathrm{M}$ during first week of growth, $\mathrm{ZnSO}_{4} 0.25 \mathrm{M}, \mathrm{NaCl} 0.25 \mathrm{M}$ during second week of growth and $\mathrm{NaCl} 0.25 \mathrm{M}$ in third week of growth. In Pak-Afgoi maize the minimum growth was observed in the plants treated with $\mathrm{NaCl} @ 0.5 \mathrm{M}$ and $0.25 \mathrm{M}$ solution (Table 1). In Raka-Poshi maize the maximum growth in roots was observed in $\mathrm{T}_{9}\left(\mathrm{ZnSO}_{4} 0.5 \mathrm{M}+\mathrm{MgSO}_{4} 0.25 \mathrm{M}\right)$ followed by $\mathrm{T}_{11}\left(\mathrm{ZnSO}_{4}(0.5 \mathrm{M})+\mathrm{NaCl}(0.5 \mathrm{M})\right)$ during first and third week of plant development, however plants treated with $\left(\mathrm{ZnSO}_{4} 0.25 \mathrm{M}\right)$ also have a significant positive effect on the development of roots. The minimum growth rate was observed in the plants treated with $\mathrm{T}_{5}(\mathrm{NaCl} 0.5 \mathrm{M})$ and $\mathrm{T}_{6}(\mathrm{NaCl}$
0.25M). The same trend was observed in Pak-Afgoi maize where the minimum and underdeveloped roots was observed in $\mathrm{NaCl} 0.5 \mathrm{M})$ and $\mathrm{T}_{6}(\mathrm{NaCl} 0.25 \mathrm{M})$, also in the plants treated with $\mathrm{T}_{12}\left(\mathrm{ZnSO}_{4}(0.25 \mathrm{M})+\right.$ $\mathrm{NaCl}(0.5 \mathrm{M}))$ and $\mathrm{T}_{13}\left(\mathrm{ZnSO}_{4}(0.5 \mathrm{M})+\mathrm{NaCl}\right.$ $(0.25 \mathrm{M})$ ) less development of roots was observed than control. In Pak-Afgoi maize maximum growth was observed in $\mathrm{T}_{1}\left(\mathrm{ZnSO}_{4} 0.5 \mathrm{M}\right), \mathrm{T}_{2}\left(\mathrm{ZnSO}_{4} 0.25 \mathrm{M}\right)$ and $\mathrm{T}_{3} \quad\left(\mathrm{MgSO}_{4} \quad(0.5 \mathrm{M})\right.$ where no significant difference was observed among these.

The leaf length and leaf width were also affected by the application of different salts and same trend was observed in the data regarding the effect of salts on leaf length and leaf width. Maximum leaf length and width was observed in the plants treated mainly with $\mathrm{ZnSO}_{4}$. In raka-Poshi maize throughout the growth period of the plants the maximum leaf length was observed $T_{1}, T_{2}$ and $T_{12}$ where plants were treated with $0.5 \mathrm{M}, 0.25 \mathrm{M}$ concentration of $\mathrm{ZnSO}_{4}$ salt. Also in Pak-Afgoi maize same trend was observed regarding leaf length where maximum leaf length was observed $T_{1}$ and $T_{8}$ where the seeds were treated with $0.5 \mathrm{M}$ and $0.25 \mathrm{M} \mathrm{ZnSO}_{4}$ separately and in combination with $\mathrm{MgSO}_{4} \quad 0.5 \mathrm{M}$ respectively. The maximum number of leaf width was observed in $\mathrm{T}_{10}$ $\left(\mathrm{ZnSO}_{4} 0.25 \mathrm{M}+\mathrm{MgSO}_{4} 0.25 \mathrm{M}\right)$ the other data show a non-significant improvement in leaf width with different salt treatments. The significantly low leaf length and leaf width was observed in the plants that were primed $30 \mathrm{mg} / \mathrm{l}$ salicylic acid solution under $\mathrm{NaCl}$ treatments and in terms of both leaf length and leaf width throughout the growth period of the plants the minimum leaf length and leaf width was observed in $\mathrm{T}_{5}$ and $\mathrm{T}_{6}$ where the plants were primed with 30 $\mathrm{mg} / \mathrm{l}$ salicylic acid solution under treatment of $0.5 \mathrm{M}$ and $0.25 \mathrm{M}$ of $\mathrm{NaCl}$ solution. The Maximum fresh shoot weight was observed in $T_{2}$ where the plants that were primed with $30 \mathrm{mg} / \mathrm{l}$ salicylic acid solution in both of Raka-Poshi and Pak-Afgoi maize genotypes under $0.5 \mathrm{M} \mathrm{ZnSO}_{4}$ which was significantly higher than all other treatments however the lowest fresh shoot weight was observed in the plants treated with $\mathrm{NaCl} 0.5 \mathrm{M}$ and $0.25 \mathrm{M}$ in the treatments $\mathrm{T}_{5}$ and $\mathrm{T}_{6}$ which was significantly different than all other treatments. The lowest fresh root weight was also observed in $T_{5}$ and $T_{6}$ where the seeds were primed with $30 \mathrm{mg} / \mathrm{l}$ salicylic acid solution. However, in Raka-Poshi maize genotype the maximum fresh root

[Citation: Iqbal, S., Ali, Q., Malik, A. (2021). Effects of seed priming with salicylic acid on Zea mays seedlings grown under salt stress conditions. Biol. Clin. Sci. Res. J., 2021: 65. doi: https://doi.org/10.54112/bcsrj.v2021i1.65] 
weight was observed in $T_{9}$ followed by $T_{11}$ and $T_{12}$ in which $\mathrm{ZnSO}_{4}$ was used in combination with $\mathrm{MgSO}_{4}$ $0.25 \mathrm{M}$ and $\mathrm{NaCl} @ 0.5 \mathrm{M}$ treatments respectively. In Pak-Afgoi maize genotype the maximum fresh root weight was observed in the plants that were primed with $30 \mathrm{mg} / \mathrm{l}$ salicylic acid solution under $\mathrm{ZnSO}_{4} 0.25$ $\mathrm{M}$ treatments throughout the growth period.

The maximum dry shoot and dry root weight in both white and yellow maize was also observed in $\mathrm{T}_{1}$ and $\mathrm{T}_{2}$ where the seeds were primed with water under $0.5 \mathrm{M}$ and $0.25 \mathrm{M}$ of $\mathrm{NaCl}$ treatments. Minimum dry shoot and root weight was observed in the plants that were primed with $30 \mathrm{mg} / \mathrm{l}$ salicylic acid solution under $\mathrm{NaCl}$ treatment separately or in combination with other salts. In Raka-Poshi genotype throughout the plant growth period minimum dry shoot weight was observed in $\mathrm{T}_{5}$ and $\mathrm{T}_{6}$ where the seeds were primed $30 \mathrm{mg} / \mathrm{l}$ salicylic acid solution while under with $0.5 \mathrm{M}$ and $0.25 \mathrm{M} \mathrm{NaCl}$ treatments respectively.
However regarding dry root weight of the plants the minimum weight was observed $\mathrm{T}_{13}$ and $\mathrm{T}_{14}$ where $0.25 \mathrm{M} \mathrm{NaCl}$ solution was used with $0.5 \mathrm{M}$ and $0.25 \mathrm{M}$ of $\mathrm{ZnSO}_{4}$ respectively. It was observed from this study that the plant growth parameters improved with the use of $\mathrm{ZnSO}_{4} @ 0.5 \mathrm{M}$ and $0.25 \mathrm{M}$ solution used for seed priming alone or in combination with $\mathrm{MgSO}_{4}$. However, no significant improvement in plant growth traits was observed when seed was primed with $30 \mathrm{mg} / \mathrm{l}$ salicylic acid solution under salt treatments of $\mathrm{ZnSO}_{4}$ was use in combination with other salts. It was also observed from the study that $\mathrm{NaCl}$ retard the growth of plant when even $30 \mathrm{mg} / \mathrm{l}$ salicylic acid solution used for priming. Minimum number of plant parameters reading was observed in the case where treated with $\mathrm{NaCl}$ alone @0.5M and $0.25 \mathrm{M}$. However when $\mathrm{NaCl}$ is used in combination with other salts it also slow the capacity of plant growth.

TABLE 1. EFFECT OF DIFFERENT SALTS ON SHOOT LENGTH OF ZEA MAYS

\begin{tabular}{|c|c|c|c|c|c|c|c|}
\hline \multirow{3}{*}{\multicolumn{2}{|c|}{ TREATMENTS }} & \multicolumn{3}{|c|}{$\begin{array}{l}\text { VARIETY 1 } \\
\text { (Raka-Poshi) }\end{array}$} & \multicolumn{3}{|c|}{$\begin{array}{l}\text { VARIETY } 2 \\
\text { (Pak-Afgoi) }\end{array}$} \\
\hline & & $1^{\text {st }}$ & $2^{\text {nd }}$ & $3^{\text {rd }}$ & $1^{\text {st }}$ & $2^{\text {nd }}$ & $3^{\text {rd }}$ \\
\hline & & WEEK & WEEK & WEEK & WEEK & WEEK & WEEK \\
\hline $\mathbf{T}_{0}$ & Control & 35.6 & 40.9 & 50.8 & 32.7 & 41.4 & 49.6 \\
\hline $\mathbf{T}_{1}$ & $\mathrm{ZnSO}_{4}(0.5 \mathrm{M})$ & 43.7 & 49.3 & 57.2 & 36.3 & 49 & 56.8 \\
\hline $\mathbf{T}_{2}$ & $\mathrm{ZnSO}_{4}(0.25 \mathrm{M})$ & 38.1 & 45.7 & 55.1 & 33.8 & 43.6 & 52.8 \\
\hline $\mathbf{T}_{\mathbf{3}}$ & MgSO4 (0.5 M) & 35.2 & 42.6 & 52.0 & 32.1 & 40.9 & 50.1 \\
\hline $\mathbf{T}_{4}$ & $\mathrm{MgSO}_{4}(0.25 \mathrm{M})$ & 40.6 & 43.8 & 51.5 & 37 & 45.5 & 51.3 \\
\hline $\mathbf{T}_{5}$ & $\mathrm{NaCl}(0.5 \mathrm{M})$ & 32.5 & 38.2 & 45.6 & 29.5 & 35.8 & 41.2 \\
\hline $\mathbf{T}_{6}$ & $\mathrm{NaCl}(0.25 \mathrm{M})$ & 33.1 & 37.4 & 43.9 & 23.8 & 33.2 & 39.6 \\
\hline $\mathbf{T}_{7}$ & $\mathrm{ZnSO}_{4}(0.5 \mathrm{M})+\mathrm{MgSO}_{4}(0.5 \mathrm{M})$ & 37.4 & 44.3 & 52.3 & 33.8 & 38.0 & 50.2 \\
\hline $\mathbf{T}_{8}$ & $\mathrm{ZnSO}_{4}(0.25 \mathrm{M})+\mathrm{MgSO}_{4}(0.5 \mathrm{M})$ & 41.3 & 48.4 & 53.4 & 39 & 45.1 & 53.2 \\
\hline $\mathbf{T}_{9}$ & $\mathrm{ZnSO}_{4}(0.5 \mathrm{M})+\mathrm{MgSO}_{4}(0.25 \mathrm{M})$ & 31.0 & 37.5 & 47.5 & 30.5 & 41.4 & 48.8 \\
\hline $\mathbf{T}_{10}$ & $\mathrm{ZnSO} 4(0.25 \mathrm{M})+\mathrm{MgSO}_{4}(0.25 \mathrm{M})$ & 34.2 & 39.4 & 48.9 & 33.2 & 42.8 & 50.8 \\
\hline $\mathbf{T}_{11}$ & $\mathrm{ZnSO}_{4}(0.5 \mathrm{M})+\mathrm{NaCl}(0.5 \mathrm{M})$ & 34.4 & 38.7 & 47.5 & 31.5 & 35 & 48.6 \\
\hline $\mathbf{T}_{12}$ & $\mathrm{ZnSO}_{4}(0.25 \mathrm{M})+\mathrm{NaCl}(0.5 \mathrm{M})$ & 38.0 & 44.1 & 52.2 & 33.4 & 37 & 47.8 \\
\hline $\mathbf{T}_{13}$ & $\mathrm{ZnSO}_{4}(0.5 \mathrm{M})+\mathrm{NaCl}(0.25 \mathrm{M})$ & 32.0 & 38.2 & 49.5 & 30 & 39.3 & 47.5 \\
\hline $\mathbf{T}_{14}$ & $\mathrm{ZnSO} 4(0.25 \mathrm{M})+\mathrm{NaCl}(0.25 \mathrm{M})$ & 34.0 & 36.4 & 45.5 & 31.2 & 37 & 46.4 \\
\hline $\mathbf{T}_{15}$ & $\begin{array}{l}\mathrm{ZnSO}_{4}(0.5 \mathrm{M})+\mathrm{MgSO}_{4}(0.5 \mathrm{M})+\mathrm{NaCl} \\
(0.5 \mathrm{M})\end{array}$ & 38.0 & 43.0 & 51.2 & 32.5 & 42.6 & 50 \\
\hline $\mathbf{T}_{16}$ & $\begin{array}{l}\mathrm{ZnSO}_{4}(0.25 \mathrm{M})+\mathrm{MgSO}_{4}(0.25 \mathrm{M})+\mathrm{NaCl} \\
(0.25 \mathrm{M})\end{array}$ & 42.0 & 48.1 & 51.9 & 39.8 & 46.5 & 50.7 \\
\hline & $\mathbf{C V}$ & 16.41 & 5.2 & 3.77 & 14.9 & 3.19 & 2.64 \\
\hline & S.E \pm & 4.8 & 1.796 & 1.54 & 3.82 & 1.070 & 2.159 \\
\hline \multicolumn{8}{|c|}{ TABLE 2. EFFECT OF DIFFERENT SALTS ON ROOT LENGTH OF ZEA MAYS } \\
\hline \multirow{3}{*}{\multicolumn{2}{|c|}{ TREATMENTS }} & \multicolumn{3}{|c|}{$\begin{array}{l}\text { VARIETY 1 } \\
\text { (Raka-Poshi) }\end{array}$} & \multicolumn{3}{|c|}{$\begin{array}{l}\text { VARIETY } 2 \\
\text { (Pak-Afgoi) }\end{array}$} \\
\hline & & $1^{\text {st }}$ & $2^{\text {nd }}$ & $3^{\text {rd }}$ & $1^{\text {st }}$ & $2^{\text {nd }}$ & $3^{\text {rd }}$ \\
\hline & & WEEK & WEEK & WEEK & WEEK & WEEK & WEEK \\
\hline $\mathbf{T}_{\mathbf{0}}$ & Control & 11.3 & 16.8 & 22.4 & 13.5 & 17.8 & 22.4 \\
\hline $\mathbf{T}_{1}$ & $\mathrm{ZnSO}_{4}(0.5 \mathrm{M})$ & 10.5 & 16.7 & 23.6 & 17.333 & 21.6 & 26.4 \\
\hline
\end{tabular}

[Citation: Iqbal, S., Ali, Q., Malik, A. (2021). Effects of seed priming with salicylic acid on Zea mays seedlings grown under salt stress conditions. Biol. Clin. Sci. Res. J., 2021: 65. doi: https://doi.org/10.54112/bcsrj.v2021i1.65] 




[Citation: Iqbal, S., Ali, Q., Malik, A. (2021). Effects of seed priming with salicylic acid on Zea mays seedlings grown under salt stress conditions. Biol. Clin. Sci. Res. J., 2021: 65. doi: https://doi.org/10.54112/bcsrj.v2021i1.65] 




[Citation: Iqbal, S., Ali, Q., Malik, A. (2021). Effects of seed priming with salicylic acid on Zea mays seedlings grown under salt stress conditions. Biol. Clin. Sci. Res. J., 2021: 65. doi: https://doi.org/10.54112/bcsrj.v2021i1.65] 


\begin{tabular}{|c|c|c|c|c|c|c|c|}
\hline $\mathbf{T}_{9}$ & $\mathrm{ZnSO}_{4}(0.5 \mathrm{M})+\mathrm{MgSO}_{4}(0.25 \mathrm{M})$ & 1.423 & 1.569 & 2.591 & 1.421 & 1.763 & 2.105 \\
\hline $\mathbf{T}_{10}$ & $\mathrm{ZnSO} 4(0.25 \mathrm{M})+\mathrm{MgSO}_{4}(0.25 \mathrm{M})$ & 1.2 & 1.5 & 2.177 & 1.096 & 1.658 & 2.114 \\
\hline $\mathbf{T}_{11}$ & $\mathrm{ZnSO}_{4}(0.5 \mathrm{M})+\mathrm{NaCl}(0.5 \mathrm{M})$ & 1.371 & 1.74 & 2.443 & 0.863 & 1.377 & 2.026 \\
\hline $\mathbf{T}_{12}$ & $\mathrm{ZnSO}_{4}(0.25 \mathrm{M})+\mathrm{NaCl}(0.5 \mathrm{M})$ & 1.22 & 1.671 & 2.211 & 0.789 & 1.351 & 1.781 \\
\hline $\mathbf{T}_{13}$ & $\mathrm{ZnSO}_{4}(0.5 \mathrm{M})+\mathrm{NaCl}(0.25 \mathrm{M})$ & 1.2 & 1.586 & 2.323 & 0.789 & 1.149 & 1.711 \\
\hline $\mathbf{T}_{14}$ & $\mathrm{ZnSO} 4(0.25 \mathrm{M})+\mathrm{NaCl}(0.25 \mathrm{M})$ & 1.14 & 1.629 & 2.06 & 1.053 & 1.491 & 1.860 \\
\hline $\mathbf{T}_{15}$ & $\begin{array}{l}\mathrm{ZnSO}_{4}(0.5 \mathrm{M})+\mathrm{MgSO}_{4}(0.5 \mathrm{M})+\mathrm{NaCl} \\
(0.5 \mathrm{M})\end{array}$ & 1.029 & 1.114 & 1.68 & 1.018 & 1.614 & 2.061 \\
\hline $\mathbf{T}_{16}$ & $\begin{array}{l}\mathrm{ZnSO}_{4}(0.25 \mathrm{M})+\mathrm{MgSO}_{4}(0.25 \mathrm{M})+\mathrm{NaCl} \\
(0.25 \mathrm{M}) \\
\mathbf{C V} \\
\text { S.E }+\end{array}$ & $\begin{array}{l}1.049 \\
19.08 \\
0.164\end{array}$ & $\begin{array}{c}1.251 \\
9.26 \\
0.109\end{array}$ & $\begin{array}{c}1.62 \\
8.84 \\
0.150\end{array}$ & $\begin{array}{l}1.447 \\
\mathbf{2 1 . 8 2} \\
\mathbf{0 . 2 0 4}\end{array}$ & $\begin{array}{c}1.781 \\
\mathbf{8 . 9 9} \\
\mathbf{0 . 1 1 6}\end{array}$ & $\begin{array}{c}2.228 \\
8.52 \\
0.140\end{array}$ \\
\hline \multirow{2}{*}{\multicolumn{2}{|c|}{ TREATMENTS }} & \multicolumn{3}{|c|}{$\begin{array}{l}\text { VARIETY 1 } \\
\text { (Raka-Poshi) }\end{array}$} & \multicolumn{3}{|c|}{$\begin{array}{l}\text { VARIETY 2 } \\
\text { (Pak-Afgoi) }\end{array}$} \\
\hline & & $\begin{array}{c}1^{\text {st }} \\
\text { WEEK }^{-}\end{array}$ & $\begin{array}{c}2^{\text {nd }} \\
\text { WEEK }\end{array}$ & $\begin{array}{c}3^{\text {rd }} \\
\text { WEEK }^{-15}\end{array}$ & \multicolumn{3}{|c|}{$2^{\text {nd }}$} \\
\hline $\mathbf{T}_{\mathbf{0}}$ & Control & 0.538 & 0.619 & 0.7684 & 0.507 & 0.642 & 0.770 \\
\hline $\mathbf{T}_{1}$ & $\mathrm{ZnSO}_{4}(0.5 \mathrm{M})$ & 0.661 & 0.746 & 0.8652 & 0.563 & 0.760 & 0.881 \\
\hline $\mathbf{T}_{2}$ & $\mathrm{ZnSO}_{4}(0.25 \mathrm{M})$ & 0.576 & 0.691 & 0.8334 & 0.525 & 0.677 & 0.819 \\
\hline $\mathbf{T}_{3}$ & MgSO4 (0.5 M) & 0.532 & 0.644 & 0.7866 & 0.498 & 0.635 & 0.777 \\
\hline $\mathbf{T}_{4}$ & $\mathrm{MgSO}_{4}(0.25 \mathrm{M})$ & 0.614 & 0.663 & 0.779 & 0.574 & 0.706 & 0.796 \\
\hline $\mathbf{T}_{5}$ & $\mathrm{NaCl}(0.5 \mathrm{M})$ & 0.492 & 0.578 & 0.6897 & 0.458 & 0.556 & 0.639 \\
\hline $\mathbf{T}_{6}$ & $\mathrm{NaCl}(0.25 \mathrm{M})$ & 0.501 & 0.566 & 0.664 & 0.369 & 0.515 & 0.615 \\
\hline $\mathbf{T}_{7}$ & $\mathrm{ZnSO}_{4}(0.5 \mathrm{M})+\mathrm{MgSO}_{4}(0.5 \mathrm{M})$ & 0.566 & 0.671 & 0.7911 & 0.525 & 0.591 & 0.779 \\
\hline $\mathbf{T}_{8}$ & $\mathrm{ZnSO}_{4}(0.25 \mathrm{M})+\mathrm{MgSO}_{4}(0.5 \mathrm{M})$ & 0.625 & 0.732 & 0.8077 & 0.605 & 0.701 & 0.826 \\
\hline $\mathbf{T}_{9}$ & $\mathrm{ZnSO}_{4}(0.5 \mathrm{M})+\mathrm{MgSO}_{4}(0.25 \mathrm{M})$ & 0.469 & 0.568 & 0.7185 & 0.473 & 0.643 & 0.757 \\
\hline $\mathbf{T}_{10}$ & $\mathrm{ZnSO} 4(0.25 \mathrm{M})+\mathrm{MgSO}_{4}(0.25 \mathrm{M})$ & 0.517 & 0.596 & 0.7397 & 0.515 & 0.664 & 0.788 \\
\hline $\mathbf{T}_{11}$ & $\mathrm{ZnSO}_{4}(0.5 \mathrm{M})+\mathrm{NaCl}(0.5 \mathrm{M})$ & 0.52 & 0.585 & 0.7185 & 0.489 & 0.543 & 0.754 \\
\hline $\mathbf{T}_{12}$ & $\mathrm{ZnSO}_{4}(0.25 \mathrm{M})+\mathrm{NaCl}(0.5 \mathrm{M})$ & 0.575 & 0.667 & 0.7896 & 0.518 & 0.574 & 0.742 \\
\hline $\mathbf{T}_{13}$ & $\mathrm{ZnSO}_{4}(0.5 \mathrm{M})+\mathrm{NaCl}(0.25 \mathrm{M})$ & 0.484 & 0.578 & 0.7487 & 0.466 & 0.610 & 0.737 \\
\hline $\mathbf{T}_{14}$ & $\mathrm{ZnSO} 4(0.25 \mathrm{M})+\mathrm{NaCl}(0.25 \mathrm{M})$ & 0.514 & 0.551 & 0.6887 & 0.484 & 0.574 & 0.720 \\
\hline $\mathbf{T}_{15}$ & $\begin{array}{l}\mathrm{ZnSO}_{4}(0.5 \mathrm{M})+\mathrm{MgSO}_{4}(0.5 \mathrm{M})+\mathrm{NaCl} \\
(0.5 \mathrm{M})\end{array}$ & 0.575 & 0.651 & 0.7745 & 0.504 & 0.661 & 0.776 \\
\hline $\mathbf{T}_{16}$ & $\begin{array}{l}\mathrm{ZnSO}_{4}(0.25 \mathrm{M})+\mathrm{MgSO}_{4}(0.25 \mathrm{M})+\mathrm{NaCl} \\
(0.25 \mathrm{M})\end{array}$ & 0.635 & 0.728 & 0.785 & 0.618 & 0.722 & 0.787 \\
\hline & CV & 17.71 & 5.67 & 5.64 & 16.22 & 5.19 & 4.48 \\
\hline \multirow{3}{*}{\multicolumn{2}{|c|}{ TREATMENTS }} & 0.154 & 0.662 & 0.075 & 0.149 & 0.562 & 0.579 \\
\hline & & \multicolumn{3}{|c|}{$\begin{array}{l}\text { VARIETY 1 } \\
\text { (Raka-Poshi) }\end{array}$} & \multicolumn{3}{|c|}{$\begin{array}{l}\text { VARIETY 2 } \\
\text { (Pak-Afgoi) }\end{array}$} \\
\hline & & $\begin{array}{c}1^{\text {st }} \\
\text { WEEK }\end{array}$ & $\begin{array}{c}2^{\text {nd }} \\
\text { WEEK }\end{array}$ & $\begin{array}{c}3^{\text {rd }} \\
\text { WEEK }^{-}\end{array}$ & $\begin{array}{c}1^{\text {st }} \\
\text { WEEK }\end{array}$ & $\begin{array}{r}2^{\text {nd }} \\
\text { WEEK }\end{array}$ & $\begin{array}{c}3^{\text {rd }} \\
\text { WEEK }\end{array}$ \\
\hline $\mathbf{T}_{0}$ & Control & 0.077 & 0.088 & 0.110 & 0.167 & 0.220 & 0.277 \\
\hline $\mathbf{T}_{1}$ & $\mathrm{ZnSO}_{4}(0.5 \mathrm{M})$ & 0.094 & 0.107 & 0.124 & 0.214 & 0.267 & 0.326 \\
\hline $\mathbf{T}_{2}$ & $\mathrm{ZnSO}_{4}(0.25 \mathrm{M})$ & 0.082 & 0.099 & 0.119 & 0.191 & 0.272 & 0.314 \\
\hline $\mathbf{T}_{3}$ & $\mathrm{MgSO} 4(0.5 \mathrm{M})$ & 0.076 & 0.092 & 0.112 & 0.117 & 0.173 & 0.327 \\
\hline $\mathbf{T}_{4}$ & $\mathrm{MgSO}_{4}(0.25 \mathrm{M})$ & 0.088 & 0.095 & 0.111 & 0.210 & 0.299 & 0.310 \\
\hline $\mathbf{T}_{5}$ & $\mathrm{NaCl}(0.5 \mathrm{M})$ & 0.070 & 0.083 & 0.099 & 0.125 & 0.163 & 0.190 \\
\hline$T_{6}$ & $\mathrm{NaCl}(0.25 \mathrm{M})$ & 0.072 & 0.081 & 0.095 & 0.136 & 0.189 & 0.216 \\
\hline $\mathbf{T}_{7}$ & $\mathrm{ZnSO}_{4}(0.5 \mathrm{M})+\mathrm{MgSO}_{4}(0.5 \mathrm{M})$ & 0.081 & 0.096 & 0.113 & 0.198 & 0.259 & 0.287 \\
\hline $\mathbf{T}_{8}$ & $\mathrm{ZnSO}_{4}(0.25 \mathrm{M})+\mathrm{MgSO}_{4}(0.5 \mathrm{M})$ & 0.089 & 0.105 & 0.115 & 0.235 & 0.247 & 0.303 \\
\hline $\mathbf{T}_{\mathbf{9}}$ & $\mathrm{ZnSO}_{4}(0.5 \mathrm{M})+\mathrm{MgSO}_{4}(0.25 \mathrm{M})$ & 0.067 & 0.081 & 0.103 & 0.200 & 0.248 & 0.297 \\
\hline $\mathbf{T}_{10}$ & $\mathrm{ZnSO} 4(0.25 \mathrm{M})+\mathrm{MgSO}_{4}(0.25 \mathrm{M})$ & 0.074 & 0.085 & 0.106 & 0.154 & 0.234 & 0.298 \\
\hline $\mathbf{T}_{11}$ & $\mathrm{ZnSO}_{4}(0.5 \mathrm{M})+\mathrm{NaCl}(0.5 \mathrm{M})$ & 0.074 & 0.084 & 0.103 & 0.121 & 0.194 & 0.285 \\
\hline $\mathbf{T}_{12}$ & $\mathrm{ZnSO}_{4}(0.25 \mathrm{M})+\mathrm{NaCl}(0.5 \mathrm{M})$ & 0.082 & 0.095 & 0.113 & 0.111 & 0.190 & 0.251 \\
\hline $\mathbf{T}_{13}$ & $\mathrm{ZnSO}_{4}(0.5 \mathrm{M})+\mathrm{NaCl}(0.25 \mathrm{M})$ & 0.069 & 0.083 & 0.107 & 0.111 & 0.162 & 0.241 \\
\hline
\end{tabular}

[Citation: Iqbal, S., Ali, Q., Malik, A. (2021). Effects of seed priming with salicylic acid on Zea mays seedlings grown under salt stress conditions. Biol. Clin. Sci. Res. J., 2021: 65. doi: https://doi.org/10.54112/bcsrj.v2021i1.65] 


\begin{tabular}{|c|c|c|c|c|c|c|c|}
\hline $\mathbf{T}_{14}$ & $\mathrm{ZnSO} 4(0.25 \mathrm{M})+\mathrm{NaCl}(0.25 \mathrm{M})$ & 0.073 & 0.079 & 0.098 & 0.148 & 0.210 & 0.262 \\
\hline $\mathbf{T}_{15}$ & $\begin{array}{l}\mathrm{ZnSO}_{4}(0.5 \mathrm{M})+\mathrm{MgSO}_{4}(0.5 \mathrm{M})+\mathrm{NaCl} \\
(0.5 \mathrm{M})\end{array}$ & 0.082 & 0.093 & 0.111 & 0.143 & 0.227 & 0.290 \\
\hline $\mathbf{T}_{16}$ & $\begin{array}{l}\mathrm{ZnSO}_{4}(0.25 \mathrm{M})+\mathrm{MgSO}_{4}(0.25 \mathrm{M})+\mathrm{NaCl} \\
(0.25 \mathrm{M})\end{array}$ & 0.091 & 0.104 & 0.112 & 0.204 & 0.251 & 0.314 \\
\hline & $\begin{array}{c}\mathbf{C V} \\
\text { S.E } \pm\end{array}$ & $\begin{array}{c}7.48 \\
\mathbf{0 . 0 1 0}\end{array}$ & $\begin{array}{c}2.33 \\
0.003\end{array}$ & $\begin{array}{l}2.09 \\
0.003\end{array}$ & $\begin{array}{r}8.20 \\
0.017\end{array}$ & $\begin{array}{c}1.33 \\
0.003\end{array}$ & $\begin{array}{c}1.12 \\
0.002\end{array}$ \\
\hline
\end{tabular}

Conflict of interest

The authors declared absence of conflict of interest.

References

Ahmad, S., Sabir, M. R., Tanveer, A., Cheema, Z. A., \& Cheema, M. A. (1994). Effect of nitrogen application and planting density on the yield of autumn maize. Pakistan Journal of Soil Science, 9(1-2), 25-28.

Aaliya, K., Qamar, Z., Ahmad, N. I., Ali, Q., Munim, F. A., \& Husnain, T. (2016). Transformation, evaluation of gtgene and multivariate genetic analysis for morpho-physiological and yield attributing traits in Zea mays. Genetika, 48(1), 423-433.

Ali, Q., Ahsan, M., Ali, F., Aslam, M., Khan, N. H., Munzoor, M., ... \& Muhammad, S. (2013). Heritability, heterosis and heterobeltiosis studies for morphological traits of maize (Zea mays L.) seedlings. Advancements in Life sciences, 1(1): 52-63.

Ali, Q., Ali, A., Ahsan, M., Nasir, I. A., Abbas, H. G., \& Ashraf, M. A. (2014). Linex Tester analysis for morpho-physiological traits of Zea mays L seedlings. Advancements in Life sciences, 1(4), 242-253.

Ali, Q., Ahsan, M., Kanwal, N., Ali, F., Ali, A., Ahmed, W., ... \& Saleem, M. (2016). Screening for drought tolerance: comparison of maize hybrids under water deficit condition. Advancements in Life Sciences, 3(2), 51-58.

Ali, F., Ahsan, M., Ali, Q., \& Kanwal, N. (2017). Phenotypic stability of Zea mays grain yield and its attributing traits under drought stress. Frontiers in Plant Science, 8, 1397.

Anonymous. (2010). Pakistan Economic Survey 2010-11. Finance Division, Economic Advisor's Wing, Govt. of Pakistan. Islamabad, Pakistan. p.21.

Asghar, A., Ali, A., Syed, W. H., Asif, M., Khaliq, T., \& Abid, A. A. (2010). Growth and yield of maize (Zea mays L.) cultivars affected by NPK application in different proportion. Pakistan journal of Science, 62(4), 211-216.

Ashraf, M., \& Foolad, M. R. (2005). Pre- sowing seed treatment-A shotgun approach to improve germination, plant growth, and crop yield under saline and non- saline conditions. Advances in Agronomy, 88, 223271.

Basra, S. M. A., Farooq, M., Tabassum, R., \& Ahmad, N. (2005). Physiological and biochemical aspects of seed vigor enhancement treatments in fine rice. Seed Science Technology, 33, 623-628.

Broadley, M. R., White, P. J., Hammond, J. P., Zelko, I., \& Lux, A. (2007). Zinc in plants. New Phytologist, 173(4), 677-702.

Cakmak, I., Kalayc1, M., Ekiz, H., Braun, H. J., Kilınç, Y., \& Yılmaz, A. (1999). Zinc deficiency as a practical problem in plant and human nutrition in Turkey: a NATO-science for stability project. Field Crops Research, 60(1-2), 175-188.

Cheeseman, J. M. (1988). Mechanisms of salinity tolerance in plants. Plant Physiology, 87(3), 547-550.

FAO (2004). FAO Statistics Division. www.faostat.fao.org.

Farooq, M., Wahid, A., Kobayashi, N. S. M. A., Fujita, D. B. S. M. A., \& Basra, S. M. A. (2009). Plant drought stress: effects, mechanisms and management. Sustainable Agriculture, 153-188.

Farooq, M. S. M. A., Basra, S. M. A., \& Hafeez, K. (2006). Seed invigoration by osmohardening in coarse and fine rice. Seed Science and Technology, 34(1), 181-187.

Farooq, M., Basra, S. M., \& Khan, M. B. (2007). Seed priming improves growth of nursery seedlings and yield of transplanted rice. Archives of Agronomy and Soil Science, 53(3), 315-326.

Farooq, M., Basra, S. M. A., Rehman, H., \& Saleem, B. A. (2008). Seed priming enhances the performance of late sown wheat (Triticum aestivum L.) by improving chilling tolerance. Journal of Agronomy and Crop Science, 194(1), 55-60.

Farooq, M., Basra, S. M. A., Khalid, M., Tabassum, R., \& Mahmood, T. (2006). Nutrient homeostasis, metabolism of reserves, and seedling vigor as affected by seed priming in coarse rice. Botany, 84(8), 1196-1202.

[Citation: Iqbal, S., Ali, Q., Malik, A. (2021). Effects of seed priming with salicylic acid on Zea mays seedlings grown under salt stress conditions. Biol. Clin. Sci. Res. J., 2021: 65. doi: https://doi.org/10.54112/bcsrj.v2021i1.65] 
Farooq, M., Tabassum, R., \& Afzal, I. (2006). Enhancing the performance of direct seeded fine rice by seed priming. Plant Production Science, 9(4), 446-456.

Francois, L.E. and Mass, E.V. (1985) Plant Responses to Salinity: A Supplement to an Indexed Bibliography. USDA, Agricultural Research Service, ARS-24.

GOP (2012). Economic Survey of Pakistan. Finance Division, Ministry of Finance, Government of Pakistan, Islamabad.

Graham, R. D., Ascher, J. S., \& Hynes, S. C. (1992). Selecting zinc-efficient cereal genotypes for soils of low zinc status. Plant and Soil, 146(1), 241-250.

Greenway, H., \& Munns, R. (1980). Mechanisms of salt tolerance in nonhalophytes. Annual Review of Plant Physiology, 31(1), 149-190.

Gungula, D. T., Kling, J. G., \& Togun, A. O. (2003). CERES- Maize predictions of maize phenology under nitrogen- stressed conditions in Nigeria. Agronomy Journal, 95(4), 892-899.

Harris, D. (1996). The effects of manure, genotype, seed priming, depth and date of sowing on the emergence and early growth of Sorghum bicolor (L.) Moench in semi-arid Botswana. Soil and Tillage Research, 40(1-2), 73-88.

Harris, D., (2006). Development and testing of onfarm? seed priming. Advanced Agronomy, 90: 129-178.

Harris, D., Rashid, A., Miraj, G., Arif, M., \& Shah, H. (2007). 'On-farm'seed priming with zinc sulphate solution-A cost-effective way to increase the maize yields of resource-poor farmers. Field Crops Research, 102(2), 119127.

Harris, D., Rashid, A., Arif, M., \& Yunas, M. (2005). Alleviating micronutrient deficiencies in alkaline soils of the North-West Frontier Province of Pakistan: on-farm seed priming with zinc in wheat and chickpea. Micronutrients in South and South East Asia, 143-151.

Lahaye, P. A., \& Epstein, E. (1971). Calcium and salt toleration by bean plants. Physiologia Plantarum, 25(2), 213-218.

Maas, E. V., \& Grieve, C. M. (1987). Sodium- induced calcium deficiency in salt- stressed corn. Plant, Cell \& Environment, 10(7), 559-564.

Mazhar, T., Ali, Q., Rashid, M. S., \& Mailk, A. (2020). Effects of salt and drought stress on growth traits of Zea mays seedlings. Life Science Journal, 17(7), 48-54.
Mengel, K., \& Kirkby, E. A. (1982). Principles of Plant Nutrition (Intl. Potash Inst, Bern, Switzerland). Menge 1446 Principles of Plant Nutrition, 446.

Naidu, B. P., Cameron, D. F., \& Konduri, S. V. (1998, July). Improving drought tolerance of cotton by glycinebetaine application and selection. In Proceedings of the 9th Australian agronomy conference, Wagga Wagga.

Rashid, A. and Memon, K.S. (2001). Soil and fertilizer phosphorus. In: Soil Sci. National Book Foundation,Islamabad, Pakistan. (Eds.): B. Elena and R. Bantel. pp. 300-302.

Rashidi, S., Ebadi, A., Parmoon, G., Jahanbakhsh, S., \& Haghighat, Z. (2015). Effect of nitrogen source on bean growth under water deficit conditions. The Philippine Agricultural Scientist, 98(1), 279-285.

Rehm, G. and Schmitt, M. (1997). Zinc for crop production. Paper No.FO-0720-B. Univ. Minnesota.

Seyyedi, S. M., Khajeh-Hosseini, M., Moghaddam, P. R., \& Shahandeh, H. (2015). Effects of phosphorus and seed priming on seed vigor, fatty acids composition and heterotrophic seedling growth of black seed (Nigella sativa L.) grown in a calcareous soil. Industrial Crops and Products, 74, 939-949.

Uhart, S. A., \& Andrade, F. H. (1995). Nitrogen deficiency in maize: II. Carbon- nitrogen interaction effects on kernel number and grain yield. Crop Science, 35(5), 1384-1389.

Zheng, H. C. (2002). Effect of seed priming with mixed-salt solution on germination and physiological characteristics of seedling in rice (Oryza sativa L.) under stress conditions. Journal of Zhejiang University (Agriculture \& Life Sciences), 28, 175-178.

Zubair, M., Shakir, M., Ali, Q., Rani, N., Fatima, N., Farooq, S., ... \& Nasir, I. A. (2016). Rhizobacteria and phytoremediation of heavy metals. Environmental Reviews, 5(1), 112-119.

Technology

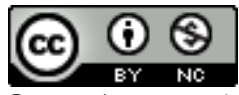

Open Access This article is licensed under a Creative Commons Attribution 4.0 International License, which permits use, sharing, adaptation, distribution and reproduction in any medium or format, as long as you give appropriate credit to the original author(s) and the source, provide a link to the Creative Commons licence, and indicate if changes were

[Citation: Iqbal, S., Ali, Q., Malik, A. (2021). Effects of seed priming with salicylic acid on Zea mays seedlings grown under salt stress conditions. Biol. Clin. Sci. Res. J., 2021: 65. doi: https://doi.org/10.54112/bcsrj.v2021i1.65] 
made. The images or other third party material in this article are included in the article's Creative Commons licence, unless indicated otherwise in a credit line to the material. If material is not included in the article's Creative Commons licence and your intended use is not permitted by statutory regulation or exceeds the permitted use, you will need to obtain permission directly from the copyright holder. To view a copy of this licence, visit http://creativecommons.org/licen ses/by/4.0/.

(C) The Author(s) 2021

[Citation: Iqbal, S., Ali, Q., Malik, A. (2021). Effects of seed priming with salicylic acid on Zea mays seedlings grown under salt stress conditions. Biol. Clin. Sci. Res. J., 2021: 65. doi: https://doi.org/10.54112/bcsrj.v2021i1.65] 